OPEN ACCESS

Edited by:

Carmine Gaeta,

University of Salerno, Italy

Reviewed by:

Grazia Maria Letizia Consoli, Institute of Biomolecular Chemistry

(ICB), Italy

Mauro Mocerino,

Curtin University, Australia

*Correspondence:

Behrouz Shaaban

shaabani.b@gmail.com

Specialty section: This article was submitted to

Supramolecular Chemistry,

a section of the journal

Frontiers in Chemistry

Received: 16 July 2019 Accepted: 17 September 2019

Published: 09 October 2019

Citation:

Bahojb Noruzi E, Kheirkhahi M, Shaabani B, Geremia S, Hickey N, Asaro F, Nitti P and Kafil HS (2019)

Design of a Thiosemicarbazide-Functionalized Calix[4]arene Ligand and Related

Transition Metal Complexes:

Synthesis, Characterization, and

Biological Studies.

Front. Chem. 7:663.

doi: $10.3389 /$ fchem.2019.00663

\section{Design of a}

Thiosemicarbazide-Functionalized Calix[4]arene Ligand and Related Transition Metal Complexes: Synthesis, Characterization, and Biological Studies

\author{
Ehsan Bahojb Noruzi ${ }^{1}$, Mahsa Kheirkhahi ${ }^{1}$, Behrouz Shaabani ${ }^{1 *}$, Silvano Geremia ${ }^{2}$, \\ Neal Hickey ${ }^{2}$, Fioretta Asaro ${ }^{2}$, Patrizia Nitti ${ }^{2}$ and Hossein Samadi Kafil ${ }^{3}$ \\ ${ }^{1}$ Department of Inorganic Chemistry, Faculty of Chemistry, University of Tabriz, Tabriz, Iran, ${ }^{2}$ Department of Chemical and \\ Pharmaceutical Sciences, University of Trieste, Trieste, Italy, ${ }^{3}$ Drug Applied Research Center, Tabriz University of Medical \\ Sciences, Tabriz, Iran
}

In this study, we synthesized a new thiosemicarbazide-functionalized calix[4]arene $\mathbf{L}$ and its $\mathrm{Co}^{2+}, \mathrm{Ni}^{2+}, \mathrm{Cu}^{2+}$, and $\mathrm{Zn}^{2+}$ transition metal complexes. For characterization several techniques were employed: Fourier-transform infrared (FT-IR), ${ }^{1} \mathrm{H}$ nuclear magnetic resonance (NMR), ${ }^{13} \mathrm{C}-\mathrm{NMR},{ }^{15} \mathrm{~N}-\mathrm{NMR}$, correlation spectroscopy (COZY), nuclear Overhauser enhancement spectroscopy (NOESY), electrospray ionization (ESI)-mass spectroscopy, scanning electron microscopy (SEM), energy-dispersive X-ray spectroscopy (EDS), and elemental analysis. To explore the capability of the thiosemicarbazide function hosted on a calix[4]arene scaffold for growth inhibition of bacteria, fungi, and cancerous tumor cells, a series of biological evaluations were performed. For $\mathbf{L}$, the antimicrobial tests revealed a higher antibacterial activity against gram-positive Bacillus subtilis and a lower activity against gram-negative bacteria (Escherichia coli and Pseudomonas aeruginosa), whereas the gram-positive Staphylococcus aureus shows resistance. All examined metal derivatives show an enhancement of the antibacterial activity against gram-negative $E$. coli bacteria, with a more significant improvement for the $\mathrm{Ni}^{2+}$ and $\mathrm{Zn}^{2+}$ complexes. MTT assays showed a considerable in vitro anticancer activity of $\mathrm{Co}^{2+}, \mathrm{Ni}^{2+}$, and $\mathrm{Cu}^{2+}$ complexes against Saos- 2 bone cancer cell lines. The activity is ascribable to the inorganic ions rather than calixarene ligand. Hemolysis assay results demonstrated that all compounds have high blood compatibility.

Keywords: thiosemicarbazide, calix[4]arene, ligand, transition metal complex, antimicrobial, anticancer 


\section{INTRODUCTION}

As the third generation of supramolecular hosts, calix $[n]$ arenes have attracted considerable attention in a wide range of either demonstrated or potential applications on the basis of their molecular recognition capabilities (Gutsche, 2008; Neri et al., 2016). These applications most notably include direct chemical sensing systems for both ions and neutral molecules (Sliwa and Girek, 2010; Brunetti et al., 2016; Sun et al., 2016; Yeon et al., 2016; Teixeira et al., 2017; Augusto et al., 2018; Cindro et al., 2018; Sarkar et al., 2018), but the host-guest chemistry of calix $[n]$ arenes has also been investigated for use in chemical extraction (Du et al., 2018), catalysis (Homden and Redshaw, 2008; Shirakawa and Shimizu, 2018), and various biological/biomedical uses (Perret and Coleman, 2011; Nimse and Kim, 2013; Durso et al., 2016).

The extensive interest in calix $[n]$ arenes is correlated with their ease of synthesis and the possibility of successive functionalization of both the upper and lower rims. This offers the possibility to introduce a wide variety of functional groups with different binding properties to fine-tune their supramolecular chemistry. Furthermore, the possibility to functionalize several arms in theory permits them to be multifunctional molecules. Specifically in the case of calix[4]arenes, the high degree of the cavity pre-organization of the cone conformation, combined with this possibility to introduce different functional groups, make them ideal candidates as molecular scaffolds in the design of novel receptors even for metal ions (Sgarlata et al., 2017; Borges et al., 2018; Gaber et al., 2018; Yousef et al., 2018).

Functionalized calixarenes are of particular interest as molecular recognition systems for biomedical applications, and they have been investigated as direct therapeutic agents (William Anthony Coleman, 2010), in drug delivery applications (Rahimi et al., 2018a, 2019), in protein recognition (Doolan et al., 2018), and in imaging applications (Mayer et al., 2018). From this point of view, a potentially interesting strategy that can be applied to calixarenes is functionalization with thiosemicarbazide groups. Thiosemicarbazide groups are functional groups whose derivatives display pharmacological properties that may be further enhanced by incorporation of metal ions (Salah et al., 2018). Thus, both free thiosemicarbazides and their metal complexes have been investigated as anticancer (Güniz Küçükgüzel and Coşkun, 2016; Xie and Peng, 2018; Xie et al., 2018), antiviral (Cihan-Üstündag et al., 2016), and antibacterial (Brahma et al., 2018; Molnar et al., 2018) agents.

The application of calix[4]arenes as receptor of hard metal ions, such as alkaline and alkaline-earth ions, is well-known (Sliwa and Girek, 2010). The incorporation of sulfur atoms introduces the possible coordination of softer transition metal ions, such as $\mathrm{Co}^{2+}, \mathrm{Ni}^{2+}, \mathrm{Cu}^{2+}$, and $\mathrm{Zn}^{2+}$, which are of particular biological interest. The metal complexation can occur through $\mathrm{S}$ and terminal $\mathrm{N}$ atoms in various ways (Campbell, 1975). For example, the metal complexes of the thiosemicarbazide molecule exhibit square planar (Yang et al., 2006), octahedral (Burrows et al., 1996), square pyramidal (Chiesi Villa et al., 1972), or tetrahedral coordination (Tong et al., 2000) for $\mathrm{Co}^{2+}, \mathrm{Ni}^{2+}$, $\mathrm{Cu}^{2+}$, and $\mathrm{Zn}^{2+}$, respectively.

The rigid structure of tert-butyl-calix[4]arenes means that up to four ligands can be introduced onto the framework through the hydroxy groups in a controlled manner. In general, two thiosemicarbazide groups would be necessary for each calixarene molecule to satisfy the coordination of a single ion. Therefore, the synthetic strategy adopted was to functionalize the 1, 3 positions of the lower rim of the tert-butyl-calix[4]arene in cone conformation.

Herein, we report the synthesis and molecular characterization of this novel calix[4] arene-based thiosemicarbazide ligand and its related complexes with some transition metal ions, expressly $\mathrm{Co}^{2+}, \mathrm{Ni}^{2+}, \mathrm{Cu}^{2+}$, and $\mathrm{Zn}^{2+}$. For these compounds, antimicrobial and anticancer activities and biocompatibility were evaluated.

\section{EXPERIMENTAL}

\section{Materials}

All chemical reagents (Merck) and solvents (Merck and Aldrich) were used as purchased without further purification. Human blood was obtained from the Iranian Blood Transfusion Institute. Mueller-Hinton agar (MHA) and Mueller-Hinton broth (MHB) were purchased from Quelab and Merck, respectively. All microorganism strains-Staphylococcus aureus (ATCC $^{\circledR}$ $29213^{\mathrm{TM}}$ ), Bacillus subtilis (ATCC ${ }^{\circledR} 6633^{\mathrm{TM}}$ ), Escherichia coli (ATCC ${ }^{\circledR} 25922^{\mathrm{TM}}$ ), Pseudomonas aeruginosa (ATCC $^{\circledR}$ $27853^{\mathrm{TM}}$ ), Candida albicans (ATCC ${ }^{\circledR} 10231^{\mathrm{TM}}$ ), and Candida glabrata (ATCC ${ }^{\circledR} 2001^{\mathrm{TM}}$ ) were provided from Persian Type Culture Collection (PTCC, Karaj, Iran) or Microbiology Department of Drug Applied Research Centre (DARC, Tabriz University, Iran).

\section{Instrumentation}

Fourier-transform infrared (FT-IR) spectra were recorded on a Bruker Tensor 27 spectrometer in the region 4,000-500 $\mathrm{cm}^{-1}$ using $\mathrm{KBr}$ pellets. Nuclear magnetic resonance $\left[{ }^{1} \mathrm{H}-\right.$ NMR, ${ }^{13} \mathrm{C}-\mathrm{NMR},{ }^{15} \mathrm{~N}-\mathrm{NMR}$, correlation spectroscopy (COZY), and nuclear Overhauser enhancement spectroscopy (NOESY)] spectra were taken on a Bruker Spectrospin Avance $400 \mathrm{MHz}$, Varian 400 and $500 \mathrm{MHz}$, and Ultra Shield spectrometer with $\mathrm{CDCl}_{3}$ solvent. For $\mathrm{L}, \mathrm{Zn}^{2+}$ titration, aliquots of $4 \mu \mathrm{L}$ of $1 \mathrm{M} \mathrm{Zn}\left(\mathrm{NO}_{3}\right)_{2} \cdot 6 \mathrm{H}_{2} \mathrm{O}$ in perdeuterated methanol were added to $0.016 \mathrm{mmol}$ of $\mathrm{L}$ in $0.6 \mathrm{~mL}$ of $\mathrm{CDCl}_{3}$ and followed by ${ }^{1} \mathrm{H}$-NMR. NMR spectra were recorded at $25^{\circ} \mathrm{C}$ after $10 \mathrm{~min}$ of equilibration time. Mass spectra were recorded on an ion trap Bruker Esquire 4000 and on a Bruker microTOF-Q, both equipped with an electrospray ionization (ESI) system. Microanalyses were carried out using a Heraeus CHN-O-Rapid analyzer. Melting points were measured on an Electrothermal 9100 apparatus. The morphology characteristic, size distribution, and percentage elemental analysis of samples were conducted via scanning electron microscopy (SEM) (field emission SEMenergy-dispersive X-ray (FESEM-EDX); TESCAN 5001). Prior to examination, samples were mounted onto a metal stub using double-sided carbon adhesive tape and covered with a 
thin layer of gold, with the aid of a direct current sputter technique (Emitech $\mathrm{k} 450 \times$, England). Furthermore, to evaluate the complexation process, elemental analysis by the energydispersive X-ray spectroscopy (EDS) technique was performed.

\section{Synthesis}

p-tert-Butylcalix[4]arene $\mathbf{1}$ was synthesized using the method published by Gutsche et al. (1981). Compound 2 (5,11,17,23-tetra-p-tert-butyl-25,27-bis[cianomethoxy]-26,28dihyroxycalix[4]arene), compound 3 (5,11,17,23-tetra- $p$-tert -butyl-25,27-bis[aminoethoxy]-26,28-dihyroxycalix[4]arene),

and compound 4 (5,11,17,23-tetra-p-tert-butyl-25,27-bis [2-isothiocyanoethoxy]-26,28-dihydroxycalix[4] arene) were synthesized using procedures reported by Collins et al. (1991), Zhang and Huang (1997), and Quiroga-Campano et al. (2017), respectively.

\section{Preparation of \\ 5,11,17,23-tetra-tert-butyl-26,28-dihydroxy-25,27- bis(thiosemicarbazidoethoxy)calix[4]arene \\ (L)}

Compound 4 ( $0.15 \mathrm{~g}, 0.18 \mathrm{mmol})$ was added at room temperature to a stirred solution of hydrazine hydrate $(90 \mu \mathrm{L}, 1.8 \mathrm{mmol})$ in ethanol $(5 \mathrm{~mL})$. Stirring was continued for $3 \mathrm{~h}$ until a clear yellow solution was obtained. The solvent was evaporated, and the final product was recrystallized from ethanol. Yield $83 \%$. mp: $280^{\circ} \mathrm{C}$ (dec.). ESI-high-resolution mass spectroscopy (HRMS): $\left[\mathrm{C}_{50} \mathrm{H}_{70} \mathrm{~N}_{6} \mathrm{O}_{4} \mathrm{~S}_{2}+\mathrm{Na}\right]^{+}$calcd: $905.4972 \mathrm{~m} / z$; found: 905.4970 $\mathrm{m} / z$; FT-IR (KBr, cm ${ }^{-1}$ ); 583, 798, 875, 937, 1,043, 1,109, 1,200, $1,297,1,363,1,476,1,542,1,618,2,871,2,957,3,049,3,437 ;{ }^{1} \mathrm{H}-$ NMR: $\left(400 \mathrm{MHz}, \mathrm{CDCl}_{3}\right.$, tetramethylsilane (TMS), $25^{\circ} \mathrm{C}, \delta$ ppm), 8.35 (s, 2 H; CNHCS), 7.63 (s, 2 H; NNHCS), 7.34 (s, $2 \mathrm{H} ; \mathrm{OH}), 7.06$ (s, $4 \mathrm{H}$; ArH), 6.86 (s, $4 \mathrm{H} ; \mathrm{ArH}), 4.21$ (d, $4 \mathrm{H}$; $\mathrm{ArCH}_{2} \mathrm{Ar}$ ), 4.27-4.17 (m, $8 \mathrm{H}$; $\mathrm{OCH}_{2} \mathrm{CH}_{2} \mathrm{NCS}$ ), 4.12-3.95 (NH2; bs, $4 \mathrm{H}), 3.37$ (d, $\left.4 \mathrm{H} ; \mathrm{ArCH}_{2} \mathrm{Ar}\right), 1.28(\mathrm{~s}, 18 \mathrm{H} ; \mathrm{t}-\mathrm{Bu}), 1.00$ (s, $18 \mathrm{H} ; t-\mathrm{Bu}) .{ }^{13} \mathrm{C}-\mathrm{NMR}\left(101 \mathrm{MHz}, \mathrm{CDCl}_{3}\right) \delta \mathrm{ppm}: 183.26$ (CS), $150.22,149.14,147.81,142.45,132.64,127.82,125.99,125.53$, $74.60\left(\mathrm{CH}_{2} \mathrm{O}\right), 44.71\left(\mathrm{CH}_{2} \mathrm{~N}\right), 34.20\left(\mathrm{C}\left(\mathrm{CH}_{3}\right)_{3}\right), 34.02\left(\mathrm{C}^{\left.\left(\mathrm{CH}_{3}\right)_{3}\right)}\right.$, $32.05\left(\mathrm{ArCH}_{2} \mathrm{Ar}\right), 31.79\left(\mathrm{CH}_{3}\right), 31.16\left(\mathrm{CH}_{3}\right) .{ }^{15} \mathrm{~N}-\mathrm{NMR}(50$ $\mathrm{MHz}, \mathrm{CDCl}_{3}, \delta$ ppm (from $\left.\mathrm{CH}_{3} \mathrm{NO}_{2}\right)$ : $-274.3\left(\mathrm{CH}_{2} \mathrm{NH}\right.$ ); other N's are not detected by ${ }^{1} \mathrm{H}_{-}{ }^{15} \mathrm{~N}$ inverse correlation due to proton exchange. Anal. Calcd. for $\mathrm{C}_{50} \mathrm{H}_{70} \mathrm{~N}_{6} \mathrm{O}_{4} \mathrm{~S}_{2}$ (883.27): C, 67.99; $\mathrm{H}$, 7.99; N, 9.51; found: C, 67.54; H, 8.24; N, 10.04 .

\section{Synthesis of Metal Complexes}

All of the complexes were synthesized as follows.

An appropriate amount of metal salts $(0.11 \mathrm{mmol})$ was dissolved in methanol $(5 \mathrm{~mL})$, and the solution was added to a tetrahydrofuran (THF) solution $(10 \mathrm{~mL})$ of ligand $\mathrm{L}(0.11$ $\mathrm{mmol}$ ). The mixture was stirred and refluxed for $24 \mathrm{~h}$, after which the precipitate was filtered and the solvent was eliminated under reduced pressure. The solid obtained was purified by crystallization using THF.

\section{Cobalt compound}

$\mathrm{Co}\left(\mathrm{NO}_{3}\right)_{2} \cdot 6 \mathrm{H}_{2} \mathrm{O}$ salt $(0.029 \mathrm{~g}, 0.11 \mathrm{mmol})$ was used as the $\mathrm{Co}^{2+}$ ion source. A dark brown powder was obtained. Yield:
90\%. mp: $230^{\circ} \mathrm{C}$ (dec.). FT-IR $\left(\mathrm{KBr}, \mathrm{cm}^{-1}\right), 588,635,674$, 783, 819, 873, 920, 1,039, 1,120, 1,199, 1,384, 1,482, 1,637, 2,871, 2,958, 3,345. ESI-MS: $\left[\mathrm{C}_{50} \mathrm{H}_{69} \mathrm{~N}_{6} \mathrm{O}_{4} \mathrm{~S}_{2} \mathrm{Co}\right]^{+}$calcd: 940.4 $\mathrm{m} / z$; found: $940.4 \mathrm{~m} / z$; $\left[\mathrm{C}_{50} \mathrm{H}_{68} \mathrm{~N}_{6} \mathrm{O}_{4} \mathrm{~S}_{2} \mathrm{Co}\right]^{+}$calcd: $939.4 \mathrm{~m} / z$; found: $939.4 \mathrm{~m} / \mathrm{z}$.

\section{Nickel compound}

$\mathrm{Ni}\left(\mathrm{NO}_{3}\right)_{2} \cdot 6 \mathrm{H}_{2} \mathrm{O}$ salt $(0.029 \mathrm{~g}, 0.11 \mathrm{mmol})$ was used as the $\mathrm{Ni}^{2+}$ ion source. A pale green powder was obtained. Yield: $44 \%$ mp: $276^{\circ} \mathrm{C}$ (dec.). FT-IR (KBr, $\left.\mathrm{cm}^{-1}\right), 587,685,747,814,873,922$, 1,038, 1,121, 1,197, 1,238, 1,370, 1,481, 1,564, 1,634, 2,095, 2,958, 3,278. ESI-MS: $\left[\mathrm{C}_{50} \mathrm{H}_{69} \mathrm{~N}_{6} \mathrm{O}_{4} \mathrm{~S}_{2} \mathrm{Ni}\right]^{+}$calcd: $939.4 \mathrm{~m} / z$; found: $939.4 \mathrm{~m} / \mathrm{z}$.

\section{Copper compound}

$\mathrm{Cu}\left(\mathrm{NO}_{3}\right)_{2} \cdot 3 \mathrm{H}_{2} \mathrm{O}$ salt $(0.27 \mathrm{~g}, 0.11 \mathrm{mmol})$ was used as the $\mathrm{Cu}^{2+}$ ion source. A green-brown powder was obtained. Yield: $68 \%$. mp: $270^{\circ} \mathrm{C}$ (dec.). FT-IR (KBr, cm $\left.{ }^{-1}\right), 583,632,689,806,873$, 1,034, 1,108, 1,196, 1,304, 1,367, 1,479, 1,576, 1,635, 2,957, 3,047, 3,397. ESI-MS: $\left[\mathrm{C}_{50} \mathrm{H}_{69} \mathrm{~N}_{6} \mathrm{O}_{4} \mathrm{~S}_{2} \mathrm{Cu}\right]^{+}$calcd: $944.4 \mathrm{~m} / z$; found: $944.4 \mathrm{~m} / \mathrm{z}$.

\section{Zinc compound}

$\mathrm{Zn}\left(\mathrm{NO}_{3}\right)_{2} \cdot 4 \mathrm{H}_{2} \mathrm{O}$ salt $(0.026 \mathrm{~g}, 0.11 \mathrm{mmol})$ was used as the $\mathrm{Zn}^{2+}$ ion source. A pale green powder was obtained. Yield: $83 \%$. mp: $208^{\circ} \mathrm{C}$ (dec.). FT-IR (KBr, cm $\left.{ }^{-1}\right)$ 581, 674, 783, 1,036, 1,115, 1,198, 1,373, 1,481, 1,635, 2,564, 2,958, 3,270. ${ }^{1} \mathrm{H}-\mathrm{NMR}:(400$ $\mathrm{MHz}, \mathrm{CDCl}_{3}, \mathrm{TMS}, 25^{\circ} \mathrm{C}, \delta \mathrm{ppm}$ ), 8.49 (s, $2 \mathrm{H} ;-\mathrm{NHCS}$ ), 7.00 (bs, $8 \mathrm{H} ; \mathrm{ArH}$ ), 4.15 (bs, $4 \mathrm{H}$; $\mathrm{ArCH}_{2} \mathrm{Ar}$ and $8 \mathrm{H} ; \mathrm{OCH}_{2} \mathrm{CH}_{2} \mathrm{NCS}$ ), 3.4 (bs, $4 \mathrm{H} ; \mathrm{ArCH}_{2} \mathrm{Ar}$ ), 1.19 (s, $18 \mathrm{H}$; t-Bu), 1.13 (s, $18 \mathrm{H} ; t-\mathrm{Bu}$ ). ${ }^{13} \mathrm{C}-\mathrm{NMR}\left(101 \mathrm{MHz}, \mathrm{CDCl}_{3}\right) \delta$ ppm: 149.2 (s), 148.7 (s), 148.0 (s), 143.0 (s), 133.2 (s), 127.5 (d), 127.1 (d) 125.6 (d), 34.4 (s, $\left.\mathrm{C}\left(\mathrm{CH}_{3}\right)_{3}\right), 34.0\left(\mathrm{~s}, \mathrm{C}\left(\mathrm{CH}_{3}\right)_{3}\right), 32.6\left(\mathrm{t}, \mathrm{ArCH}_{2} \mathrm{Ar}\right), 31.6\left(\mathrm{q}, \mathrm{CH}_{3}\right)$, $31.2\left(\mathrm{q}, \mathrm{CH}_{3}\right)$. ESI-MS: $\left[\mathrm{C}_{50} \mathrm{H}_{69} \mathrm{~N}_{6} \mathrm{O}_{4} \mathrm{~S}_{2} \mathrm{Zn}\right]^{+}$calcd: $945.4 \mathrm{~m} / z$; found: $945.5 \mathrm{~m} / \mathrm{z}$.

\section{Antimicrobial and Antifungal Studies}

The minimum inhibitory concentration (MIC) and minimum bactericidal concentration $(\mathrm{MBC})$ of the ligand and related complexes were measured using the microbroth dilution method according to the protocols described by Clinical and Laboratory Standards Institute (CLSI) (Weinstein et al., 2018). Concentration series (15.62-2,000 ppm) of the compounds were prepared in nutrient broth medium. A total of $180 \mu \mathrm{L}$ of prepared diluted solutions was transferred into sterile 96-well microtiter plates, and then $20 \mu \mathrm{L}$ of standardized microorganism suspensions was added and mixed gently to get a homogenous suspension. The concentration of the microorganisms was

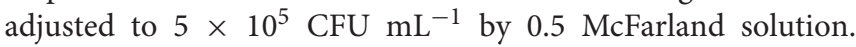
Then, the plates were incubated at $37^{\circ} \mathrm{C}$ for $24 \mathrm{~h}$ (Bahlouli et al., 2018). After incubation, turbidity was evaluated to determine bacterial growth, and the dilution with no turbidity (lack of growth) was considered as MIC. Finally, to determine the MBC, samples $(5 \mu \mathrm{L})$ from tubes in which no growth was observed were cultured in plate (containing MHA medium) and incubated for $24 \mathrm{~h}$ at $37^{\circ} \mathrm{C}$. In each test, microorganism strain in MHB (without chemicals) and MHB alone (without 
bacteria) were used as positive and negative growth controls, respectively (Karimi et al., 2018). This method was applied with S. aureus (ATCC ${ }^{\circledR} 29213^{\mathrm{TM}}$ ) and B. subtilis (ATCC ${ }^{\circledR} 6633^{\mathrm{TM}}$ ) as gram-positive bacteria, E. coli (ATCC ${ }^{\circledR} 25922^{\mathrm{TM}}$ ) and $P$. aeruginosa $\left(\mathrm{ATCC}^{\circledR} 27853^{\mathrm{TM}}\right.$ ), as gram-negative bacteria, and $C$. albicans (ATCC ${ }^{\circledR} 10231^{\mathrm{TM}}$ ) and C. glabrata $\left(\mathrm{ATCC}^{\circledR} 2001^{\mathrm{TM}}\right.$ ) as fungal strains.

\section{Cell Culture}

MCF-7 cells (human breast cancer cells) and Saos-2 cells (human bone cancer cells) were collected from the Pasteur Institute of Iran, Tehran, Iran, and maintained in RPMI 1640 medium supplemented with $10 \%$ fetal bovine serum (FBS) and 1\% benzylpenicillin/streptomycin. Further, the MCF-7 and Saos-2 cell lines were maintained at $5 \% \mathrm{CO}_{2}$ in a $\mathrm{CO}_{2}$ incubator at $37^{\circ} \mathrm{C}$ for $24 \mathrm{~h}$. Cultures were continuously viewed under a microscope to evaluate the quantity of confluence, and the absence of bacterial and fungal contaminants was confirmed. After $90 \%$ confluence was reached, the cells were detached by adding trypsin to the flask. The cell suspensions were collected and centrifuged at $1,500 \mathrm{rpm}$ for $5 \mathrm{~min}$ and re-suspended in the growth medium for further steps (Rahimi et al., 2017a).

\section{MTT Assay}

To determine the cytotoxic effect of the synthesized ligand and its related metal compounds, a cell viability study was done with the MTT reduction assay. MCF-7 and Saos- 2 cells were seeded at a density of $1 \times 10^{4}$ cells/well in 96-well plates. The cells were incubated overnight and treated with $\mathbf{L}$ or one of the metal complexes at the concentrations of 200, 100, and 50 ppm for $48 \mathrm{~h}$ using untreated cells as control. Afterward, the culture media were exchanged with $180 \mathrm{~mL}$ of fresh culture media and $20 \mathrm{~mL}$ of MTT solution $\left(2 \mathrm{mg} \mathrm{mL}^{-1}\right)$ and incubated at $37^{\circ} \mathrm{C}$ for $4 \mathrm{~h}$. The MTT solution was removed and replaced with $200 \mu \mathrm{L}$ of dimethyl sulfoxide (DMSO) followed by 20 min incubation time. The absorbance of each well (dissolved formazan crystals) was measured at a wavelength of $570 \mathrm{~nm}$ using an enzyme-linked immunosorbent assay (ELISA) reader (ShafieiIrannejad et al., 2018). The results were given as the mean of three independent experiments. The percentage of viability was calculated by absorbance values using the following formula:

$$
\text { Cell viability }(\%)=\frac{A_{\text {sample }}}{A_{\text {control }}} \times 100
$$

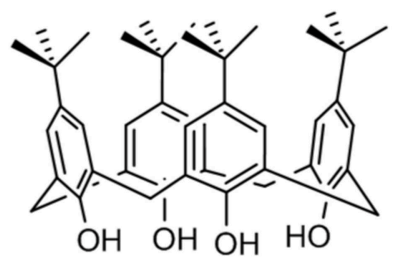

(1)

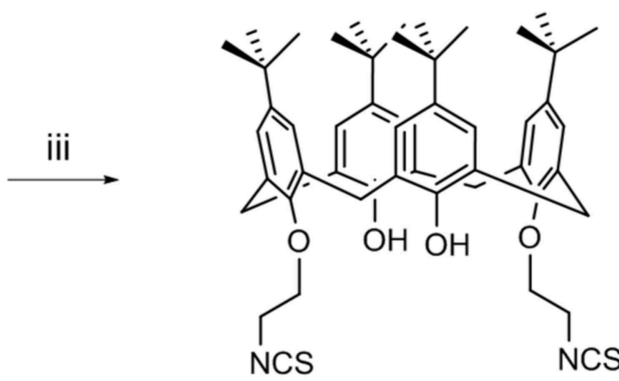

(4)

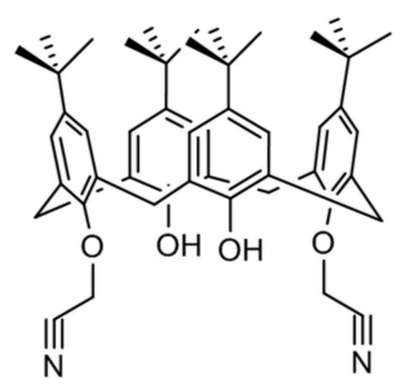

(2)

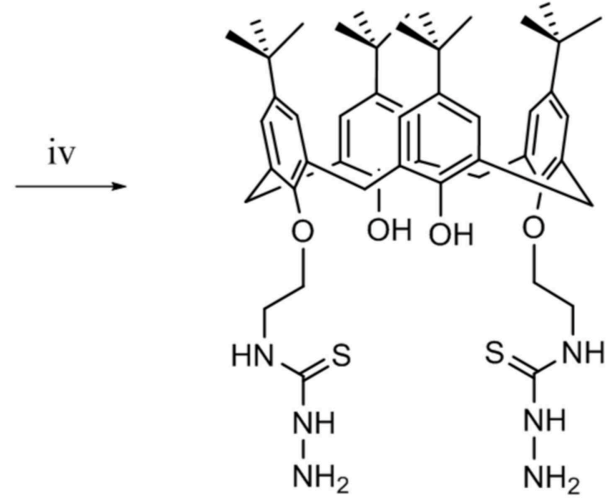

(L)

FIGURE 1 | Route followed for the synthesis of ligand L; (i) chloroacetonitrile, $\mathrm{K}_{2} \mathrm{CO}_{3}$, Nal, reflux, $7 \mathrm{~h}$; (ii) $\mathrm{LiAlH}_{4},\left(0^{\circ} \mathrm{C}\right.$ ), $4 \mathrm{~h}$; (iii) $\mathrm{CSCl}_{2}, \mathrm{BaCO}_{3}, 24 \mathrm{~h}$; (iv) hydrazine hydrate, room temperature, $3 \mathrm{~h}$. 


\section{Hemolysis Assay}

\section{Blood Collection and Erythrocyte Isolation}

Hemolysis assay was performed using fresh human blood. Approximately $5 \mathrm{~mL}$ of blood that was stabilized using EDTA was placed into a 15-mL centrifuge tube. Phosphate-buffered saline (PBS) measuring $10 \mathrm{~mL}$ was added to wash away blood proteins and serum from the red blood cells (RBCs). The erythrocytes were collected by centrifugation at $4,000 \mathrm{rpm}$ for $10 \mathrm{~min}$ at room temperature. The upper layer (plasma) was discarded, and erythrocytes (RBCs) were isolated. The RBCs were washed three times with PBS $(\mathrm{pH}=7.4)$ to obtain a clear supernatant (Rahimi et al., 2018b).

\section{Hemolytic Activity and RBC Aggregation}

The total isolated RBCs were diluted 10 times with PBS. In each microtube, $0.5 \mathrm{~mL}$ of ligand $\mathbf{L}$ or one of the metal complexes was mixed at different concentrations $(62.5,125,250,500$, and 1,000 ppm) with $0.5 \mathrm{~mL}$ of diluted RBCs and incubated at $37^{\circ} \mathrm{C}$ for $3 \mathrm{~h}$ in an incubator shaker. Diluted RBCs treated with $0.5 \mathrm{~mL}$ of water and PBS were used as positive and negative controls with $100 \%$ and $0 \%$ hemolytic effects, respectively. After incubation, all samples were centrifuged at 4,000 rpm for $5 \mathrm{~min}$. The supernatant was taken out and transferred to a 96-well plate (Rahimi et al., 2018b). An ELISA plate reader was used to measure the released hemoglobin (at a wavelength of $540 \mathrm{~nm}$ ), and the hemolysis rate was calculated via the following formula:

$$
\text { Hemolysis (\%) }=\frac{A_{\text {sample }}-A_{\text {negative }}}{A_{\text {positive }}-A_{\text {negative }}} \times 100
$$

where $A_{\text {sample }}$ is the absorbance of the testing sample, and $A_{\text {positive }}$ and $A_{\text {negative }}$ are the absorbance of the positive control and the negative control, respectively.

\section{RESULTS AND DISCUSSION \\ Development of a New \\ calix[4]arene-thiosemicarbazide Ligand \\ and Related Metal Derivatives}

The synthetic route for the preparation of 5,11,17,23-tetra-tert-butyl-26, 28-dihydroxy-25,27bis(thiosemicarbazidoethoxy)calix[4]arene (L) is shown in Figure 1.

Briefly, starting from p-tert-butylcalix[4]arene (1), a couple of hydroxyl groups on the lower rim in 1, 3 alternate positions were transformed to cyanomethoxy by chloroacetonitrile (2). The reduction of cyano functional groups with $\mathrm{LiAlH}_{4}$ gave the corresponding diamine derivative (3). Then, the diisothiocyanate derivative (4) was obtained by the reaction of compound 3 with thiophosgene in high yield. Finally, the reaction of compound 4 with an excess amount of hydrazine hydrate in ethanol at room temperature resulted in the new calixarene-thiosemicarbazide derivative (L).

Several divalent metal derivatives of $\mathbf{L}\left(\mathrm{Co}^{2+}, \mathrm{Ni}^{2+}, \mathrm{Cu}^{2+}\right.$, and $\mathrm{Zn}^{2+}$ ) were prepared by mixing one equivalent of the metal salt in $\mathrm{MeOH}$ with one equivalent of ligand $\mathbf{L}$ in THF followed by reflux for $24 \mathrm{~h}$.

\section{Characterization}

Several techniques (FT-IR, ${ }^{1} \mathrm{H}-\mathrm{NMR},{ }^{13} \mathrm{C}-\mathrm{NMR},{ }^{15} \mathrm{~N}-\mathrm{NMR}$, COZY, NOESY, MS, CHN analysis, SEM, and EDS analysis) were

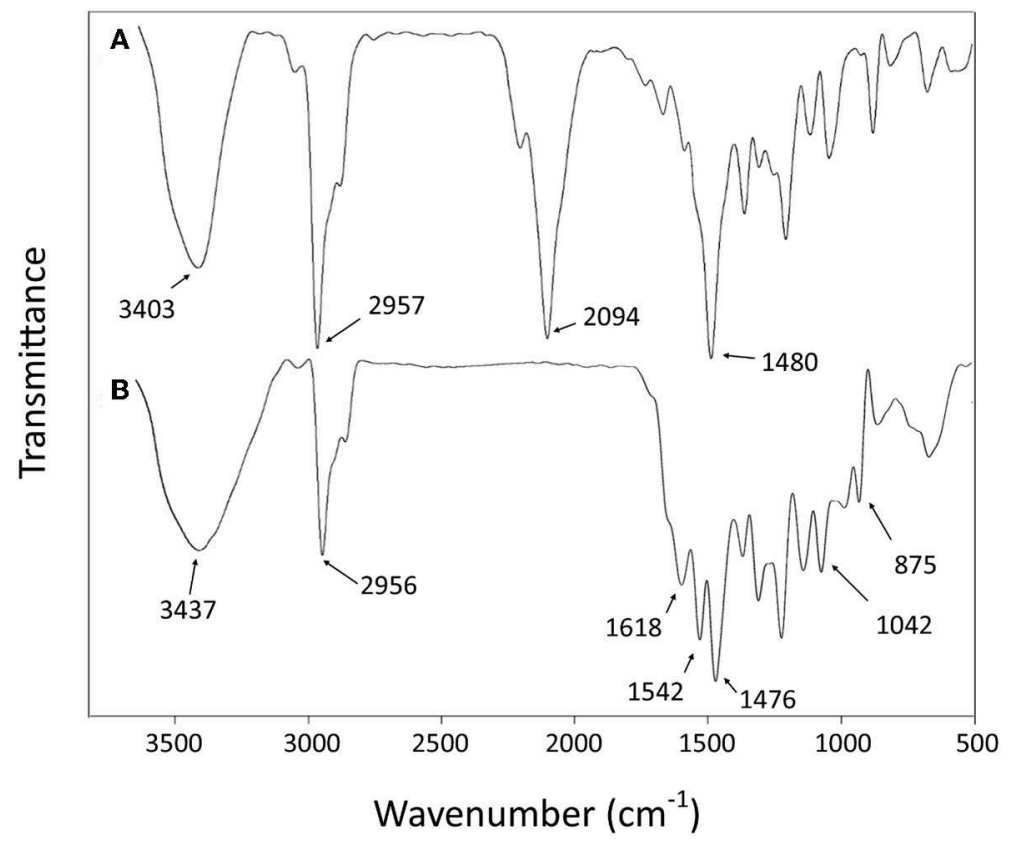

FIGURE 2 | Fourier-transform infrared (FT-IR) spectra of compound $\mathbf{4}$ (A) and ligand $\mathbf{L}$ (B). 
performed to confirm the preparation route of the ligand and metal derivatives.

\section{FT-IR}

The success of the final step of synthesis is confirmed by the analysis of the FT-IR spectra. The absence of the strong peak at $2,094 \mathrm{~cm}^{-1}$ from the spectrum of $\mathbf{L}$, assigned to the stretching mode of CN in the NCS group of $\mathbf{4}$ (Yamamoto et al., 1992), is the most noteworthy feature that indicates the transformation of isothiocyanate functional group (Figure 2). The disappearance of this peak should be accompanied by the appearance of new bands related to stretching and bending vibrations of the formed thiosemicarbazide group, such as the new bands observed at $1,620-1,540 \mathrm{~cm}^{-1}$, which can be attributed to the $v(-\mathrm{N}-\mathrm{C}=\mathrm{S})$ vibrations (Rao and Venkataraghavan, 1962). The band at 875 $\mathrm{cm}^{-1}$ can be attributed to the stretching of the $\mathrm{C}=\mathrm{S}$ group (Mostafa, 2007). Furthermore, the absence of any bands in the $2,600-2,550 \mathrm{~cm}^{-1}$ range assignable to $v(\mathrm{SH})$ stretching suggests that the CS group remains in thione form (Mostafa, 2007). The expected $\mathrm{N}-\mathrm{H}$ bond stretching of the thiosemicarbazide group lies within the broad envelope of the peak centered at 3,437 $\mathrm{cm}^{-1}$, which also contains the $\mathrm{O}-\mathrm{H}$ stretching (Silverstein et al., 1991; Rastogi et al., 2002). The other bands, corresponding to C$\mathrm{H}, \mathrm{C}=\mathrm{C}$, and $\mathrm{C}-\mathrm{C}$ vibrational modes of aromatic rings (Baldini et al., 2003; Hernández et al., 2016), are conserved in both 4 and L spectra.

The comparison of the FT-IR spectra of $\mathbf{L}$ and the derivative metal complexes evidences a main feature that supports the metal coordination by $\mathbf{L}$. The characteristic double peak of the $\mathrm{N}-\mathrm{C}=\mathrm{S}$ vibration observed for $\mathrm{L}$ in the $1,620-1,540 \mathrm{~cm}^{-1}$ region shifts to higher wave number in all metal derivatives. These differences are summarized in Table 1, and the corresponding spectra are reported in the Supporting Information.

This observation is in agreement with the hypothesis of a metal coordination by $\mathbf{L}$ for all bivalent ions, with a possible formation of a five-member cycle involving the terminal $\mathrm{N}$-atom and $\mathrm{S}$-atom responsible for the profile change of the $\mathrm{N}-\mathrm{C}=\mathrm{S}$ vibration bands.

\section{NMR}

The ${ }^{1} \mathrm{H}$-NMR spectra of compound 4 (Figure $3 \mathrm{~A}$ ) show two singlet signals for two sets of $18 t$-Bu protons $(\delta 0.97$ and 1.29 $\mathrm{ppm}$ ), two doublet signals ( $\delta 3.36 \mathrm{ppm}, 4$ protons; and $\delta 4.25 \mathrm{ppm}$, 4 protons) assigned to the calixarene $-\mathrm{CH}_{2}$ - bridging groups, a multiplet peak ( $\delta 4.22-4.14 \mathrm{ppm})$ corresponding to the eight $\mathrm{OCH}_{2} \mathrm{CH}_{2} \mathrm{NCS}$ protons, two types of aromatic protons $(\delta 6.86$ ppm, 4 protons; and $\delta 7.06 \mathrm{ppm}, 4$ protons) as two singlet signals, and one singlet peak related to two $\mathrm{OH}$ protons $(\delta 6.89 \mathrm{ppm})$ in agreement with literature data (Quiroga-Campano et al., 2017).

The ${ }^{1} \mathrm{H}-\mathrm{NMR}$ spectra of ligand $\mathbf{L}$ (Figure $3 \mathbf{B}$ ) show analogous signals for the protons that correspond to those in $\mathbf{4}$, in addition to a broad singlet for the four terminal $\mathrm{NH}_{2}$ protons $(\delta 4.12-$ $3.95 \mathrm{ppm})$, a singlet peak attributed to two thiosemicarbazide $\mathrm{NH}$ protons $(\delta 7.63 \mathrm{ppm})$, and a singlet signal attributed to two NHCS protons ( $\delta 8.35 \mathrm{ppm})$. The singlet peak corresponding to two $\mathrm{OH}$ proton $(\delta 7.34 \mathrm{ppm})$ appears at a significantly higher chemical shift than observed for compound 4 ( $\delta 6.89 \mathrm{ppm})$. The ${ }^{1} \mathrm{H}-\mathrm{NMR}$ assignment was supported by the $\mathrm{H}-\mathrm{H}$ and $\mathrm{H}-\mathrm{C}$ two-dimensional (2D) NMR spectra (see Supporting Information). Thus, these spectra are in agreement with the synthesis of the new calixarene derivative $\mathbf{L}$.

The complexation of the metal ions was investigated by NMR only for the diamagnetic $\mathrm{Zn}^{2+}$ ion. The addition of a $\mathrm{Zn}\left(\mathrm{NO}_{3}\right)_{2}$ solution to the $\mathbf{L}$ sample provokes a general broadening and shift of ${ }^{1} \mathrm{H}-\mathrm{NMR}$ signals depending of the type of protons involved. In particular, the signals of protons of the p-tert-butyl of phenyl groups functionalized by the thiosemicarbazide arms (a) and the corresponding aromatic hydrogens (f) are the most affected (Figure 4).

Owing to the overall broadening of the signals, the two strongest singlets due to sets of 18 tert-butyl protons $(\mathrm{a}, \mathrm{b})$ are the best indicators to follow the complexation process. The stepwise addition of $\mathrm{Zn}^{2+}$ ions causes a downfield shift of the (a) protons, whereas the (b) protons are shifted upfield. In particular, the (a) signal shows a slight shift upon the first addition of a $\mathrm{Zn}^{2+}$. Then with the second addition of $\mathrm{Zn}^{2+}$ ion $\left(\mathrm{L}: \mathrm{Zn}^{2+}\right.$ ratio $\left.=1: 0.5\right)$, a split of the (a) signal becomes evident. The two signals ( $\mathrm{a}^{\prime}$ and $\left.\mathrm{a}^{\prime \prime}\right) 0.1 \mathrm{ppm}$ apart that have approximately equal intensity can be attributed to species with unbound and bound $\mathrm{Zn}^{2+}$ ions, respectively. When the titration reaches the 1-to-1 ratio, the $\left(a^{\prime}\right)$ signal disappears in favor to the $\left(\mathrm{a}^{\prime \prime}\right)$ signal of the $\mathrm{Zn}^{2+}$ complex. Contemporarily, a significant downfield shift of the aromatic proton (f) is observed. This titration experiment clearly shows the coordination properties of the $\mathbf{L}$ ligand and the formation of a 1-to-1 stoichiometric complex.

\section{ESI-MS}

The HRMS of ligand $\mathbf{L}$ showed molecular ion peaks corresponding to the sodium adduct of the $\mathbf{L}$ ligand (Supporting Information). The most intense peak of $905.4790 \mathrm{~m} / \mathrm{z}$ perfectly agrees with a compound with formula $\mathrm{C}_{50} \mathrm{H}_{70} \mathrm{~N}_{6} \mathrm{O}_{4} \mathrm{~S}_{2}$ (theoretical $[\mathrm{M}+\mathrm{Na}]^{+}$equal to $905.4792 \mathrm{~m} / z$ ) and confirms the proposed structure for $\mathbf{L}$.

Evidence of formation of the complexes was obtained by ESI-MS (Supporting Information). All spectra show peaks

TABLE 1 | IR spectral data $\left(\mathrm{cm}^{-1}\right)$ of the ligand and its corresponding complexes in $\mathrm{KBr}$ pellets.

\begin{tabular}{|c|c|c|c|c|c|}
\hline \multirow[t]{2}{*}{ Vibrational mode } & \multicolumn{5}{|c|}{ Frequency $\left(\mathrm{cm}^{-1}\right)$} \\
\hline & Ligand L & Complex Co & Complex Ni & Complex Cu & Complex Zn \\
\hline $\mathrm{N}-\mathrm{C}=\mathrm{S}$ & $1,618,1,542$ & 1,637, sh & $1,634,1,564$ & $1,635,1,576$ & $1,635, \mathrm{sh}$ \\
\hline
\end{tabular}

IR, infrared. 

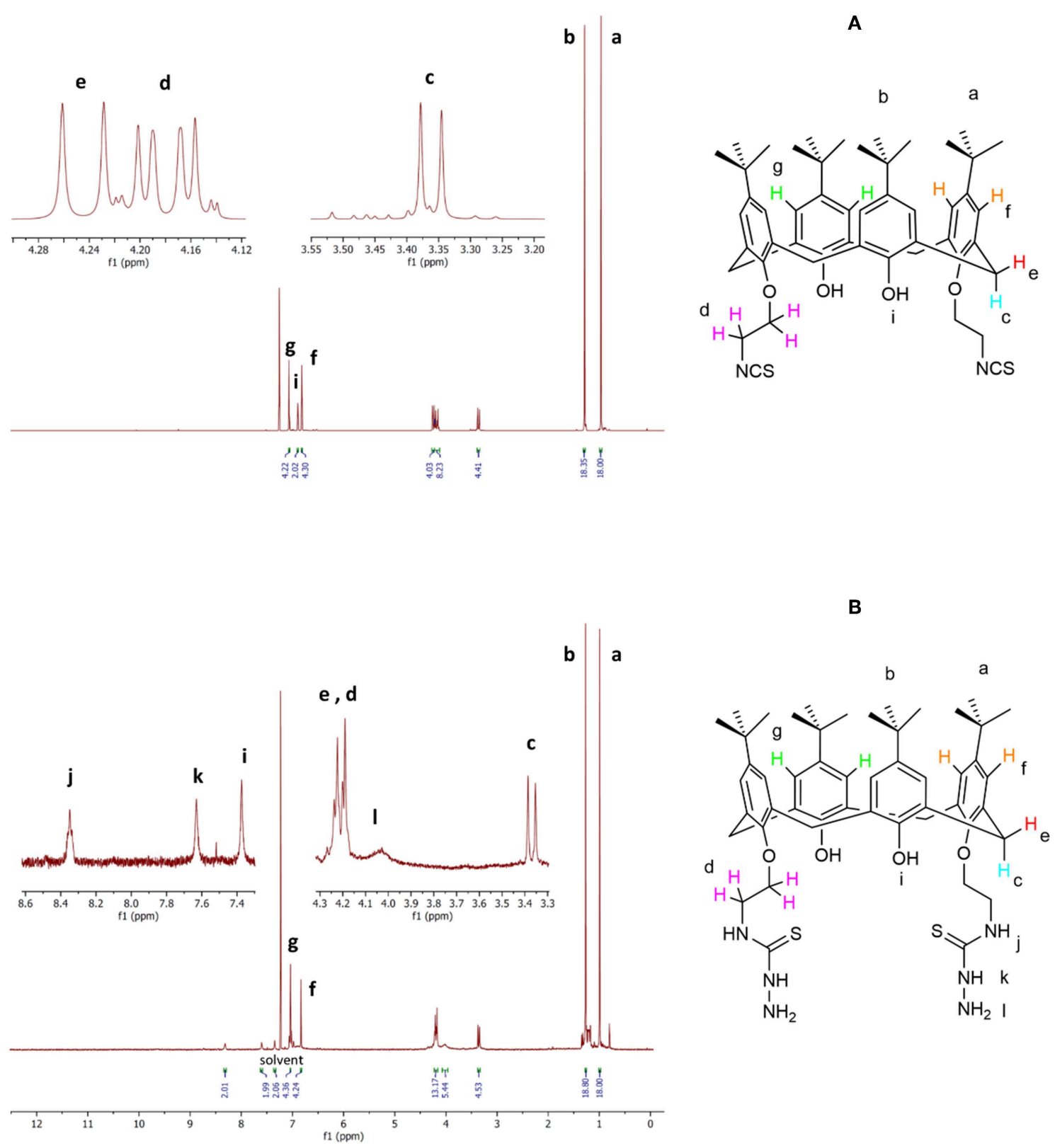

FIGURE 3 | Selected portion of the ${ }^{1} \mathrm{H}-\mathrm{NMR}$ spectra of compound $\mathbf{4}$ (A) and ligand $\mathbf{L}$ (B).

related to multiple species along with evidence for formation of the metal ion complexes. The spectrum for the Co adduct shows the presence of $\mathrm{Co}^{2+}$ bound by a deprotonated $\mathbf{L}$ ligand $\left(\left[\mathrm{C}_{50} \mathrm{H}_{69} \mathrm{~N}_{6} \mathrm{O}_{4} \mathrm{~S}_{2} \mathrm{Co}\right]^{+}, \mathrm{m} / z\right.$ 940.4) superimposed with an amount of $\mathrm{Co}^{3+}$ species bound by a doubly deprotonated L ligand $\left(\left[\mathrm{C}_{50} \mathrm{H}_{68} \mathrm{~N}_{6} \mathrm{O}_{4} \mathrm{~S}_{2} \mathrm{Co}\right]^{+}, m / z\right.$ 939.4). It should be noted that the deprotonation of two hydroxy groups of calix[4]arene is consistent with formation of an octahedral coordination environment ideal for complexation of $\mathrm{Co}^{3+}$ species. The spectrum of $\mathrm{Ni}$ derivative, in which an ion is usually involved in octahedral coordination, shows the clearest evidence of metal complexation of those investigated. The most intense peaks are related to the mono-deprotonated $\mathrm{L}$ ligand coordinated to $\mathrm{Ni}^{2+}$ ion $\left(\left[\mathrm{C}_{50} \mathrm{H}_{69} \mathrm{~N}_{6} \mathrm{O}_{4} \mathrm{~S}_{2} \mathrm{Ni}\right]^{+}\right.$, $\mathrm{m} / z$ 939.4). In the case of $\mathrm{Cu}^{2+}$ and $\mathrm{Zn}^{2+}$, the MS show a series of peaks related to the $\left[\mathrm{C}_{50} \mathrm{H}_{69} \mathrm{~N}_{6} \mathrm{O}_{4} \mathrm{~S}_{2} \mathrm{Cu}\right]^{+}(944.4$ $m / z)$ and $\left[\mathrm{C}_{50} \mathrm{H}_{69} \mathrm{~N}_{6} \mathrm{O}_{4} \mathrm{~S}_{2} \mathrm{Zn}\right]^{+}(945.5 \mathrm{~m} / z)$ complexes, respectively. For both species, the isotopic distribution shows some small discrepancy in the intensity with respect to the calculated distributions.

\section{SEM}

The morphological characteristics of the solid-state aggregation of ligand $\mathbf{L}$ and its metal derivatives were evaluated using a SEM 


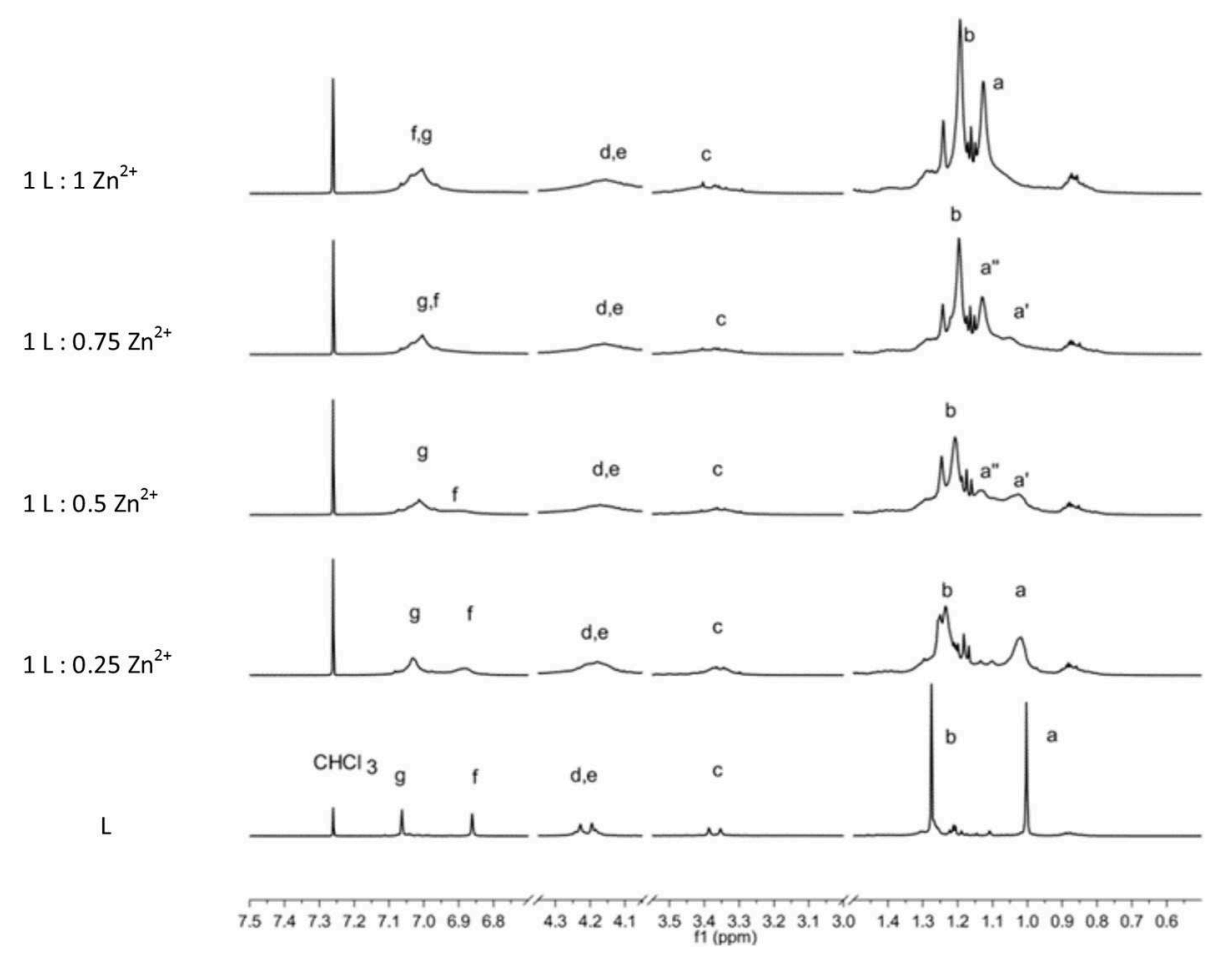

FIGURE $4 \mid{ }^{1} \mathrm{H}-\mathrm{NMR}$ spectrum sequence of titration of $\mathbf{L}$ by $\mathrm{Zn}^{2+}$ ions. The bottom spectra of $\mathbf{L}$ are scaled by a factor of 0.2 .

by applying $15-\mathrm{kV}$ electron acceleration voltage. Figures $5 \mathrm{~A}-\mathbf{D}$ shows the SEM images of ligand $\mathbf{L}$ and of its metal derivatives at $20 \times$ magnification. In comparison with $\mathbf{L}$, each metal derivative shows a different morphology of the aggregation state, with a more crystalline tendency in the case of the $\mathrm{Zn}$ derivative (Figure 5E).

\section{EDS}

EDS or EDX was used to semi-quantitatively measure chemical elements of compounds. As indicated by the EDS chemical maps, the presence of $\mathrm{Co}, \mathrm{Ni}, \mathrm{Cu}$, and $\mathrm{Zn}$ metals is confirmed in the corresponding metal derivative samples (Figure 6). The analysis of the data suggests that the percentage of metal ions in the $\mathrm{Cu}^{2+}$ and $\mathrm{Zn}^{2+}$ samples is somewhat higher than that observed for the $\mathrm{Ni}^{2+}$ and $\mathrm{Co}^{2+}$ derivatives.

\section{In vitro Antimicrobial Activity and Antifungal Evaluation}

The biological properties of thiosemicarbazide derivatives have been studied extensively in recent years by different research groups (Liesen et al., 2010; Plech et al., 2011; Shebl et al., 2013; Rane et al., 2014). Herein, the in vitro antimicrobial and antifungal activities of the synthesized compounds ( $\mathbf{L}$ and complexes of $\mathbf{C o}, \mathbf{N i}, \mathbf{C u}$, and $\mathbf{Z n}$ ) were evaluated using the microbroth dilution method against the aforementioned standard strains. None of the investigated compounds show a measurable antifungal activity. However, as shown in Table 2, the free ligand $\mathbf{L}$ has an effective antibacterial activity against gram-positive B. subtilis, whereas the gram-positive $S$. aureus was resistant to it. A lower activity was observed for both investigated gram-negative pathogens (E. coli and P. aeruginosa). The cobalt complex showed a moderate antibacterial activity against all of the bacteria except $B$. subtilis that showed resistance. The antibacterial properties against the gram-negative strains were significantly enhanced upon coordination of nickel to the thiosemicarbazide ligand, whereas no variations are observed for gram-positive bacteria. Specifically, in the case of E. coli strain, the MIC and MBC values show fourfold and two-fold decreases, respectively. The coordination of copper metal to the ligand improved the MIC and MBC values against $S$. aureus and $E$. coli strains. On the other hand, the MIC values against $B$. subtilis and $P$. aeruginosa were not affected by this metal addition, whereas the MBC values against these two strains were enhanced. In comparison with $\mathbf{L}$, the zinc complex improved the antibacterial activity toward $S$. aureus and both gram-negative bacteria. In the case of $E$. coli and $P$. aeruginosa strains, the MIC values show eight-fold and two-fold decreases, respectively. On the other hand, the MBC values against all of the microorganisms (except $P$. aeruginosa) were improved significantly, with a 16fold decrease against E. coli. Overall, all compounds have some antibacterial activities against gram-negative strains, and some of them showed an antibacterial activity against grampositive bacteria. The decreased MIC and MBC values of metal derivatives are consistent with the possibility that they disturb the respiration process of the bacterial cell, blocking the synthesis of proteins, which restricts growth of the microorganism (Dharmaraj et al., 2001). 


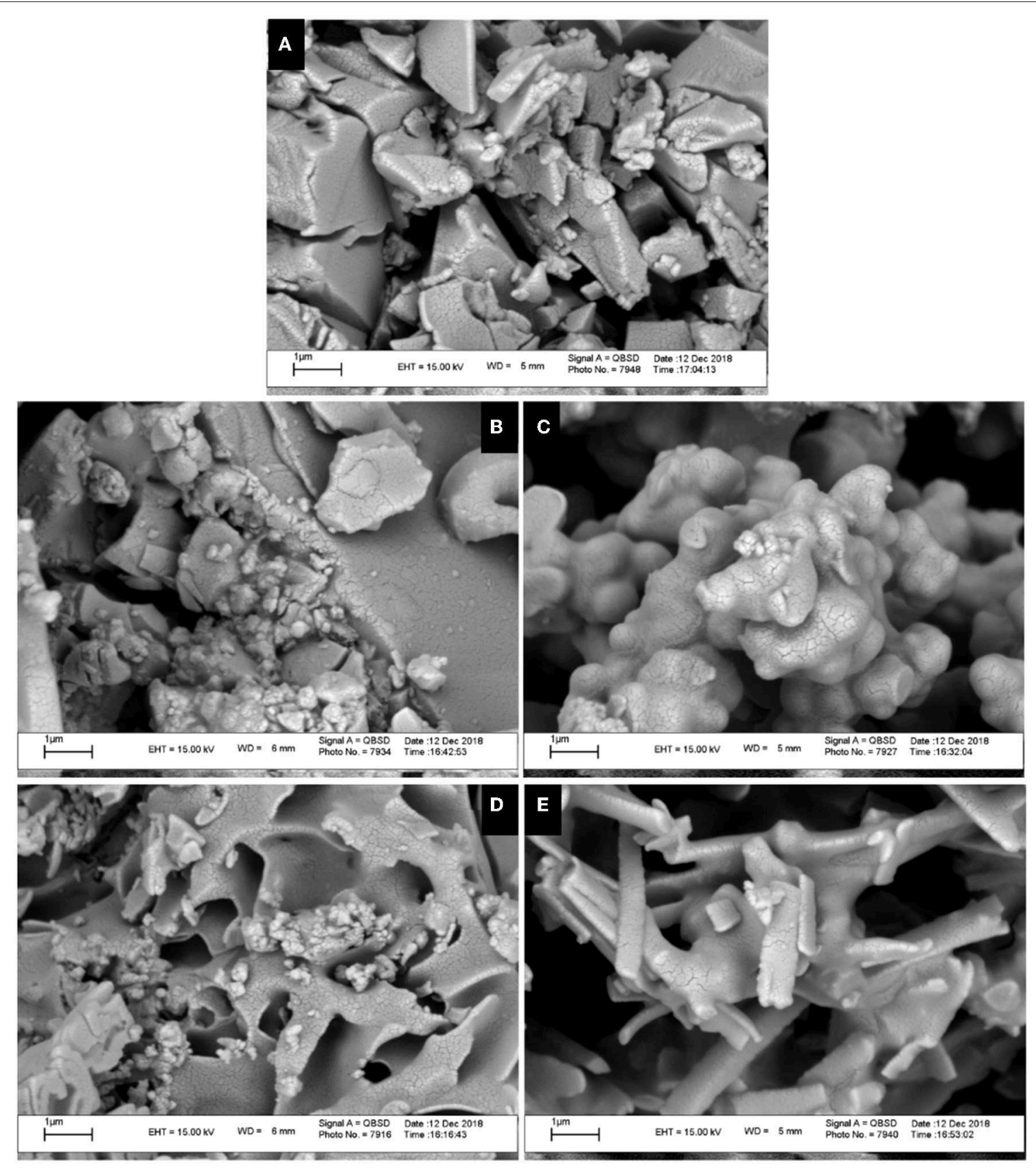

FIGURE 5 | Scanning electron microscopy (SEM) images of ligand $\mathbf{L}$ (A) and complexes Co (B), Ni (C), Cu (D), and $\mathbf{Z n}$ (E) at the scale of $1 \mu \mathrm{m}$.

\section{MTT Assay}

According to previous studies, the anticancer activities of calixarene-based compounds are related to their enzyme inhibition potential (Cherenok et al., 2006, 2012), inhibiting tumor angiogenesis (Dings et al., 2006) and DNA replication of cancer cells (Consoli et al., 2007). The cytotoxicity of the ligand and complexes was studied against the MCF-7 and Saos-2 cell lines by MTT assay. All of the compounds were dispersed in water (and 10\% DMSO) and diluted with cell culture medium to reach three required concentrations $(50,100$, and
$200 \mathrm{ppm}$ ). The cytotoxicity impact on cell growth is shown in Figure 7. In general, all of the compounds showed a very low antiproliferative activity against MCF-7, whereas for the Saos-2 cells, a more significant dose-dependent antiproliferative activity was observed with exclusion of $\mathbf{L}$ and the $\mathbf{Z n}$ derivative. The Co derivative showed an excellent anticancer activity against the Saos-2 cell line even at a lower concentration (42.13\%), although the most effective toxicity is revealed at a higher concentration (16.34\%). At a higher concentration, the activities of $\mathbf{N i}$ and $\mathbf{C u}$ derivatives are also evident, with inhibition concentrations $\left(\mathrm{IC}_{50}\right)$ 

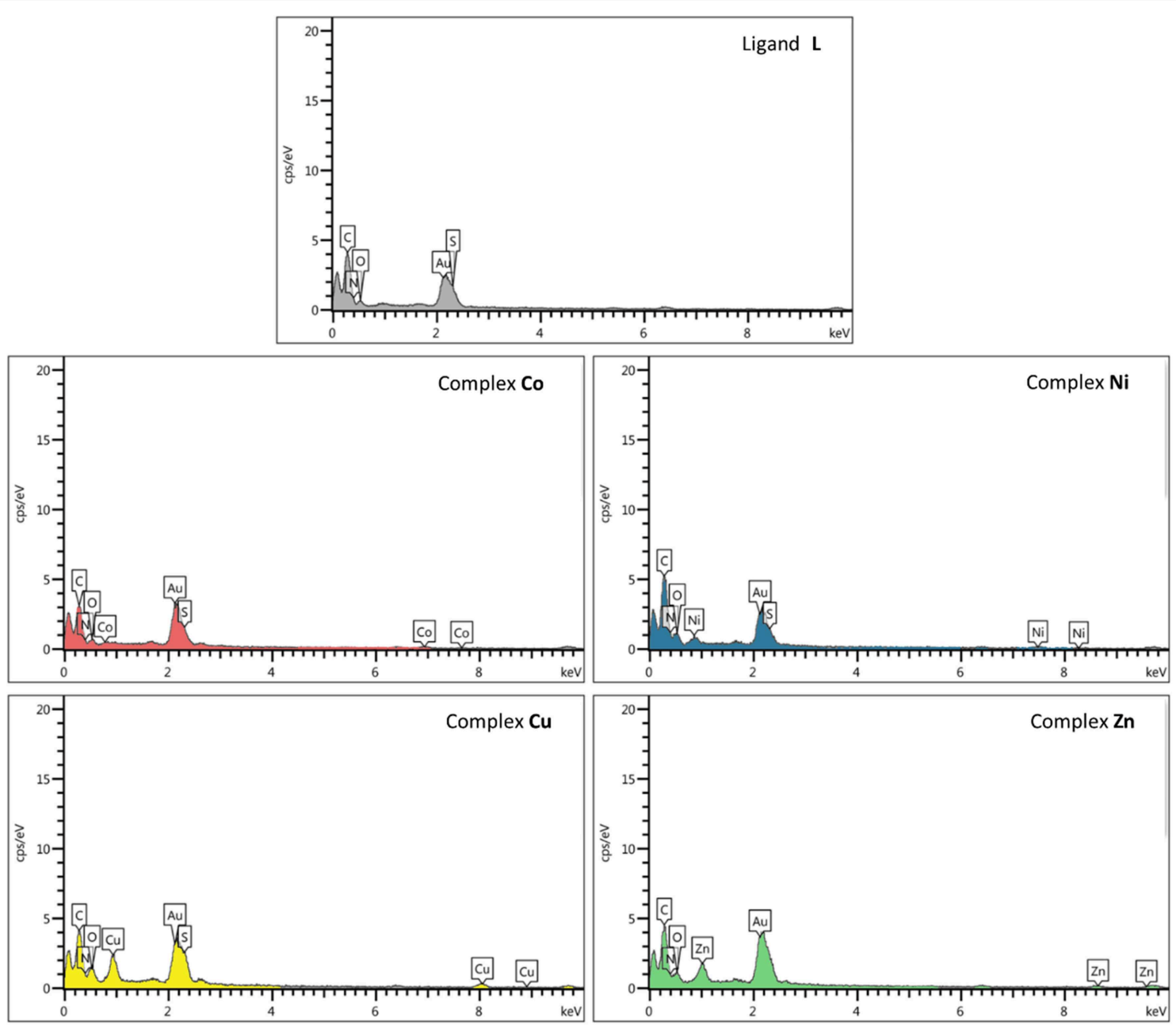

FIGURE 6 | Scanning electron microscopy-energy-dispersive X-ray (SEM-EDX) elemental analysis of ligand $\mathbf{L}$ and complexes $\mathbf{C o}, \mathbf{N i}, \mathbf{C u}$, and $\mathbf{Z n}$.

TABLE 2 | Antibacterial activity of synthesized compounds against different microorganisms in with the microbroth dilution method.

\begin{tabular}{|c|c|c|c|c|c|}
\hline \multicolumn{2}{|c|}{ Microorganisms } & \multicolumn{2}{|c|}{ Gram positive } & \multicolumn{2}{|c|}{ Gram negative } \\
\hline & Complex Co & 250 & - & 125 & 125 \\
\hline & Complex $\mathbf{N i}$ & - & 31.25 & 62.50 & 31.25 \\
\hline & Complex Cu & 250 & 31.25 & 125 & 62.50 \\
\hline \multirow[t]{5}{*}{ MBC } & Ligand L & - & - & 500 & - \\
\hline & Complex Co & - & - & 500 & 500 \\
\hline & Complex $\mathbf{N i}$ & - & - & 250 & - \\
\hline & Complex Cu & 250 & 31.25 & 250 & 250 \\
\hline & Complex Zn & 500 & 125 & 31.25 & - \\
\hline
\end{tabular}

The antibacterial activity is expressed as the MIC and MBC (ppm). MIC, minimum inhibitory concentration; MBC, minimum bactericidal concentration.

"Gentamicin used as standard control for bacteria. 

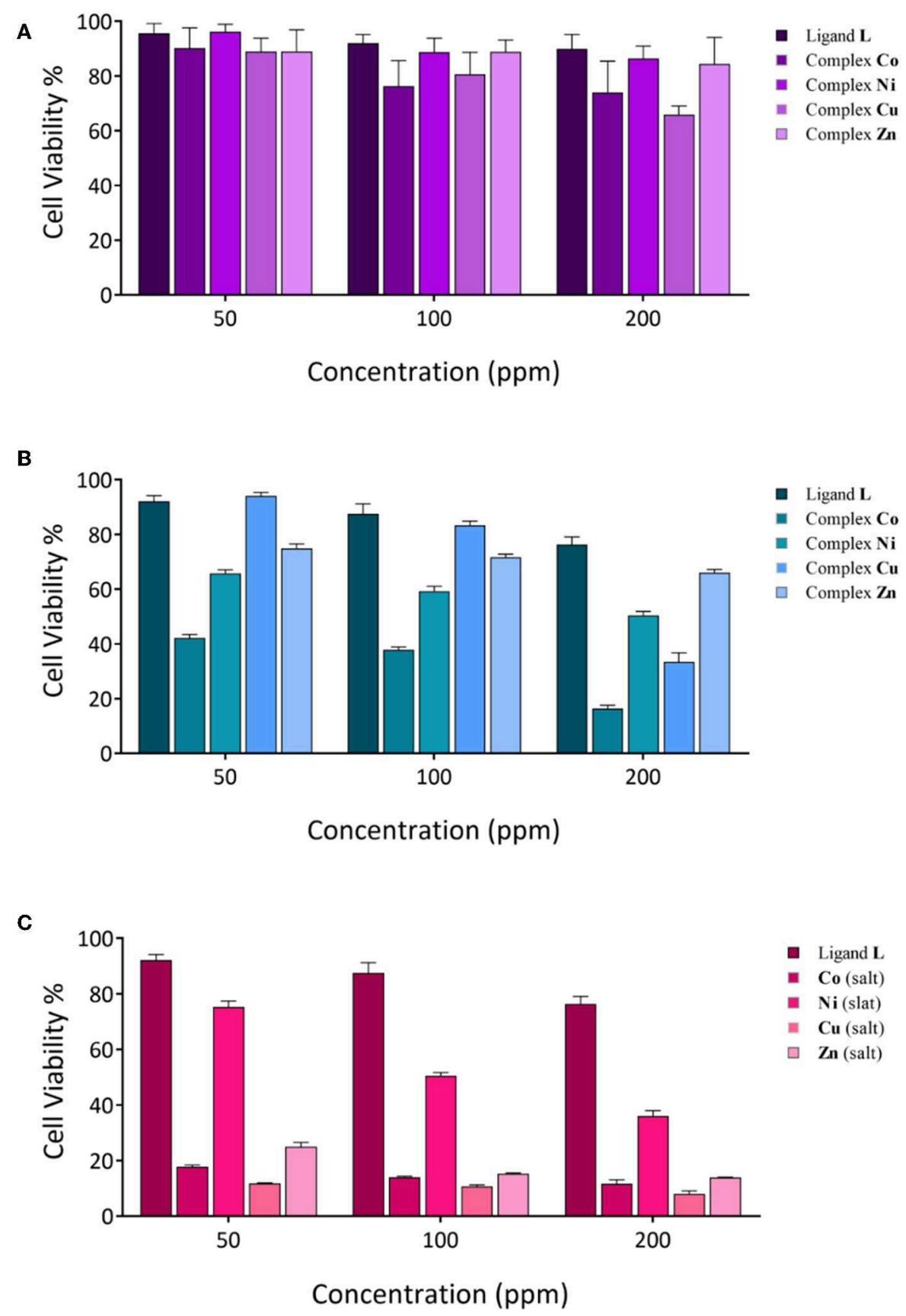

FIGURE 7 | Cytotoxicity evaluation of synthesized compounds at various concentrations against cancer cell lines; (A) MCF-7 cell lines; (B,C), Saos-2 cell lines.

over $48 \mathrm{~h}$ of 200 and $170 \mathrm{ppm}$, respectively. However, control assays performed with the corresponding inorganic salts show that the activity is mainly ascribable to the inorganic component rather than the organic calixarene component. Actually, the L ligand appears to protect the cells against the inherent cytotoxicity of the bivalent ions present in the inorganic salts of these metals.

\section{Hemolysis Assay}

Hemolysis assay was performed to examine the biocompatibility and the cytotoxic effect of ligand and complexes on RBCs at different concentrations. As shown in Figure 8, dose-dependent hemolytic effects of the prepared compounds on RBCs were observed, and the results confirm that there are only slight hemolytic effects from the compounds at high dosages. RBCs 

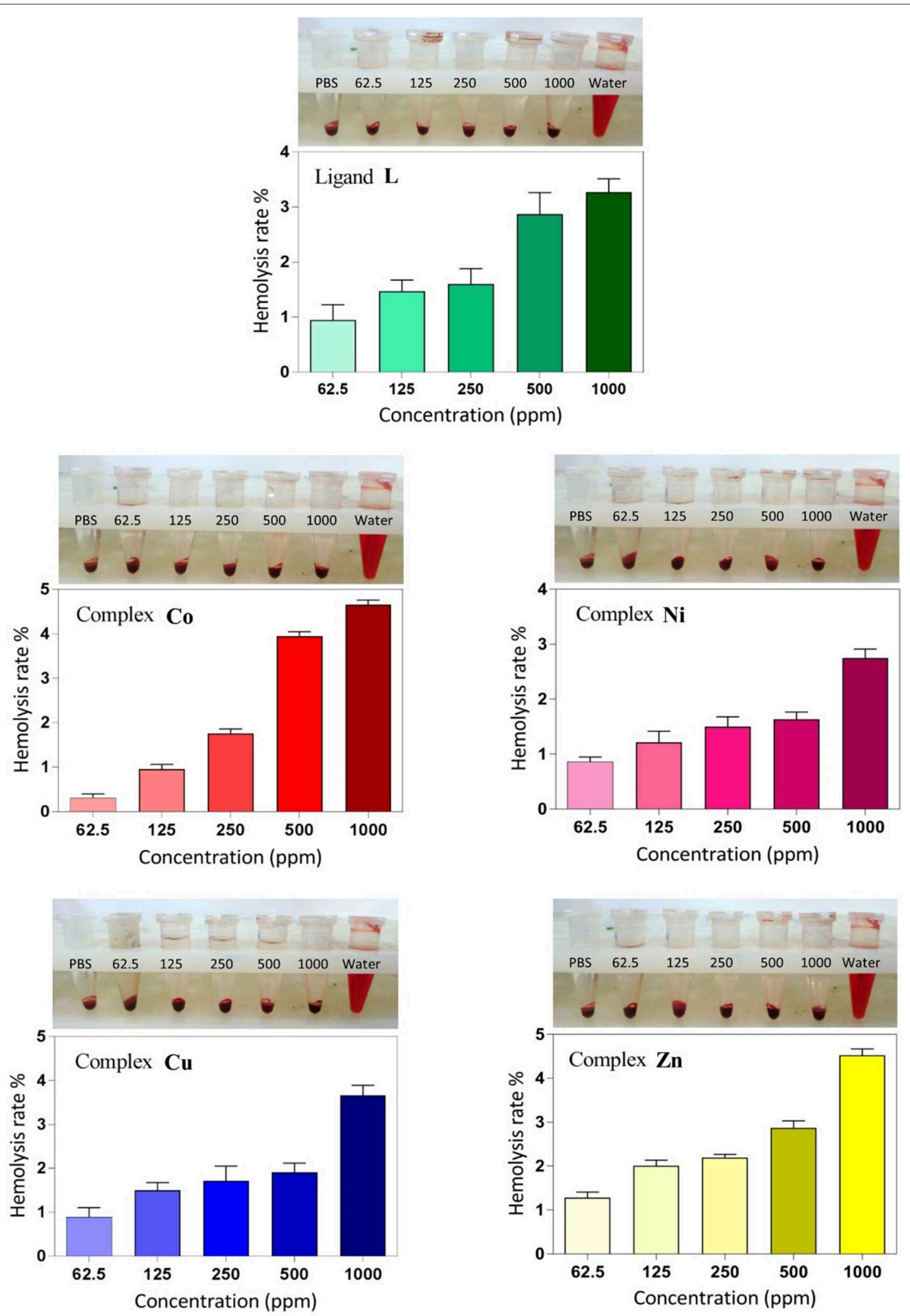

FIGURE 8 | Hemolysis rate of human red blood cells (HRBCs) in the presence of the synthesized samples and the visual observation of hemoglobin in the supernatant at different concentrations (ppm). 
were also treated with PBS and deionized water as negative and positive controls, respectively. With regard to the results, at the highest concentration investigated $(1,000 \mathrm{ppm})$, the lowest hemolytic activity was observed for the Ni derivative (2.6\%), whereas at the lowest concentration investigated $(62.5 \mathrm{ppm})$, the lowest hemolytic activity was observed for the Co derivative $(0.3 \%)$. Therefore, on the basis of biocompatibility of the various compound investigated, the $\mathbf{N i}$ and Co complexes could be the best choices for biological applications in higher and lower concentrations, respectively. Also, the hemolytic activity of the ligand itself is very low (3.18\%) and $<4.5 \%$, which is an acceptable threshold for hemolytic activity (Rahimi et al., 2017b).

\section{CONCLUSION}

In this study, we designed and synthetized a new calix[4]arenebased thiosemicarbazide molecule, and we used it as a quadridentate ligand to prepare a series of transition metal complexes. The characterization with multiple techniques (FT-IR, ${ }^{1} \mathrm{H}$ NMR, ${ }^{13} \mathrm{C}-\mathrm{NMR},{ }^{15} \mathrm{~N}-\mathrm{NMR}$, COZY, NOESY, ESI-MS, SEM, EDS, and elemental analysis) demonstrated the success of the synthesis of the target ligand, $\mathbf{L}$. The ability of $\mathbf{L}$ to complex metal ions was demonstrated by ${ }^{1} \mathrm{H}-\mathrm{NMR}$ titration experiments with the diamagnetic $\mathrm{Zn}^{2+}$ ions. On the basis of the known biological properties of thiosemicarbazide derivatives, we performed antimicrobial and anticancer evaluations against human cancer cell lines and biocompatibility studies on $\mathbf{L}$ and the series of its metal complexes to investigate $\mathrm{Co}^{2+}$, $\mathrm{Ni}^{2+}, \mathrm{Cu}^{2+}$, and $\mathrm{Zn}^{2+}$. $\mathbf{L}$ showed a higher antibacterial activity against gram-positive $B$. subtilis and a lower activity against gram-negative bacteria (E. coli and $P$. aeruginosa), whereas the gram-positive $S$. aureus shows resistance. All metal derivatives show an enhancement of the antibacterial activity against gramnegative bacteria (except for the $\mathrm{Co}^{2+}$ and $\mathrm{Cu}^{2+}$ derivatives for $P$. aeruginosa), with a more significant improvement for the $\mathrm{Ni}^{2+}$ and $\mathrm{Zn}^{2+}$ complexes. The anticancer activities of all compounds against the MCF-7 cell line were not relevant, even if the activities of the $\mathrm{Co}$ and $\mathbf{C u}$ complexes slightly improved at a higher concentration. On the other hand, the MTT assay appeared to show a significant anticancer activity of $\mathrm{Co}^{2+}, \mathrm{Ni}^{2+}$, and $\mathrm{Cu}^{2+}$ complexes against Saos-2 cell line. However, control assays show that this activity is mainly ascribable to the metal ions rather than the organic

\section{REFERENCES}

Augusto, A. S., Miranda, A. S., Ascenso, J. R., Miranda, M. Q., Félix, V., Brancatelli, G., et al. (2018). Anion recognition by partial cone dihomooxacalix[4]arenebased receptors bearing urea groups: remarkable affinity for benzoate ion. Eur. J. Org. Chem. 2018, 5657-5667. doi: 10.1002/ejoc.201800880

Bahlouli, S., Aghazadeh, Z., Aghazadeh, M., Shojani, S., and Kafil, H. S. (2018). Determining the antibacterial activity of chlorhexidine mouthwashes with and without alcohol against common oral pathogens. J. Adv. Oral Res. 9, 15-19. doi: $10.1177 / 2229411218762045$

Baldini, M., Belicchi-Ferrari, M., Bisceglie, F., Pelosi, G., Pinelli, S., and Tarasconi, P. (2003). Cu(II) complexes with heterocyclic substituted thiosemicarbazones: the case of 5-formyluracil. Synthesis, characterization, $\mathrm{x}$-ray structures, DNA calixarene component. Hemolysis assays demonstrated no significant hemolysis rate for all of the compounds even at higher concentrations.

\section{DATA AVAILABILITY STATEMENT}

All datasets generated for this study are included in the manuscript/Supplementary Files.

\section{ETHICS STATEMENT}

All biological studies were carried out under approved protocols with the ethical committee of Tabriz University of Medical Sciences (National Institutes of Health Publication No. 85-23, revised 1996).

\section{AUTHOR CONTRIBUTIONS}

EB and MK: substantial contributions to the conception or design of the work, or the acquisition, analysis or interpretation of data for the work. BS: research have performed under his supervision. SG and $\mathrm{NH}$ : substantial contributions to the analysis or interpretation of data for the work. FA: performed the NMR titrations of metal complexes. PN: purified some samples and helped for interpretation of NMR spectra. HK: designed and confirmed antibacterial part of research.

\section{FUNDING}

This study was financially supported by University of Tabriz.

\section{ACKNOWLEDGMENTS}

We thank Drug Applied Research Center (DARC), Tabriz University of Medical Sciences (Tabriz, Iran), and all biological experiments in this report were done in DARC.

\section{SUPPLEMENTARY MATERIAL}

The Supplementary Material for this article can be found online at: https://www.frontiersin.org/articles/10.3389/fchem. 2019.00663/full\#supplementary-material 08.013

Brahma, U., Kothari, R., Sharma, P., and Bhandari, V. (2018). Antimicrobial and anti-biofilm activity of hexadentated macrocyclic complex of copper(II) derived from thiosemicarbazide against Staphylococcus aureus. Sci. Rep. 8:8050. doi: 10.1038/s41598-018-26483-5

Brunetti, E., Moerkerke, S., Wouters, J., Bartik, K., and Jabin, I. (2016). A selective calix[6] arene-based fluorescent chemosensor for phosphatidylcholine 
type lipids. Org. Biomol. Chem. 14, 10201-10207. doi: 10.1039/C6OB0 $1880 \mathrm{G}$

Burrows, A. D., Mingos, D. M. P., White, A. J. P., and Williams, D. J. (1996). Crystal engineering of metal complexes based on charge-augmented double hydrogen-bond interactions between thiosemicarbazides and carboxylates. Chem. Commun. 1996, 97-99. doi: 10.1039/cc9960000097

Campbell, M. J. M. (1975). Transition metal complexes of thiosemicarbazide and thiosemicarbazones. Coord. Chem. Rev. 15, 279-319. doi: 10.1016/S0010-8545(00)80276-3

Cherenok, S., Vovk, A., Muravyova, I., Shivanyuk, A., Kukhar, V., Lipkowski, J., et al. (2006). Calix[4] arene alpha-aminophosphonic acids: asymmetric synthesis and enantioselective inhibition of an alkaline phosphatase. Org. Lett. 8, 549-552. doi: 10.1021/ol052469a

Cherenok, S. O., Yushchenko, O. A., Tanchuk, V. Y., Mischenko, I. M., Samus, N. V., Ruban, O. V., et al. (2012). Calix[4] arene- $\alpha$-hydroxyphosphonic acids. Synthesis, stereochemistry, and inhibition of glutathione S-transferase. Arkivoc 4, 278-298. doi: 10.3998/ark.5550190.0013.421

Chiesi Villa, A., Manfredotti, A. G., and Guastini, C. (1972). Bis(thiosemicarbazide) copper(II) sulfate. Cryst. Struct. Commun. 1:4.

Cihan-Üstündag, G., Gürsoy, E., Naesens, L., Ulusoy-Güzeldemirci, N., and Çapan, G. (2016). Synthesis and antiviral properties of novel indole-based thiosemicarbazides and 4-thiazolidinones. Bioorg. Med. Chem. 24, 240-246. doi: 10.1016/j.bmc.2015.12.008

Cindro, N., PoŽar, J., Barišić, D., Bregović, N., Pičuljan, K., Tomaš, R., et al. (2018). Neutral glycoconjugated amide-based calix[4]arenes: complexation of alkali metal cations in water. Org. Biomol. Chem. 16, 904-912. doi: 10.1039/C7OB02955A

Collins, E. M., McKervey, M. A., Madigan, E., Moran, M. B., Owens, M., Ferguson, G., et al. (1991). Chemically modified calix[4]arenes. Regioselective synthesis of 1,3-(distal) derivatives and related compounds. X-ray crystal structure of a diphenol-dinitrile. J. Chem. Soc. Perkin Trans. 1, 3137-3142. doi: 10.1039/p19910003137

Consoli, G. M. L., Granata, G., Galante, E., Di Silvestro, I., Salafia, L., and Geraci, C. (2007). Synthesis of water-soluble nucleotide-calixarene conjugates and preliminary investigation of their in vitro DNA replication inhibitory activity. Tetrahedron 63, 10758-10763. doi: 10.1016/j.tet.2007.06.123

Dharmaraj, N., Viswanathamurthi, P., and Natarajan, K. (2001). Ruthenium (II) complexes containing bidentate Schiff bases and their antifungal activity. Transit. Metal Chem. 26, 105-109. doi: 10.1023/A:1007132408648

Dings, R. P., Chen, X., Hellebrekers, D. M., van Eijk, L. I., Zhang, Y., Hoye, T. R., et al. (2006). Design of nonpeptidic topomimetics of antiangiogenic proteins with antitumor activities. J. Natl. Cancer Inst. 98, 932-936. doi: $10.1093 /$ jnci/djj247

Doolan, A. M., Rennie, M. L., and Crowley, P. B. (2018). Protein recognition by functionalized sulfonatocalix[4]arenes. Chem. Eur. J. 24, 984-991. doi: 10.1002/chem.201704931

Du, L. J., Jiao, Y. H., Ye, L. H., Fei, T. H., Wang, Q. Y., Hu, Y. H., et al. (2018). Calixarene-based miniaturized solid-phase extraction of trace triazine herbicides from the honey and milk samples. Food Anal. Methods 11, 3283-3292. doi: 10.1007/s12161-018-1270-6

Durso, A., Brancatelli, G., Hickey, N., Farnetti, E., De Zorzi, R., Bonaccorso, C., et al. (2016). Interactions of a water-soluble calix[4]arene with spermine: solution and solid-state characterisation. Supramol. Chem. 28, 499-505. doi: 10.1080/10610278.2015.1125900

Gaber, M., Fayed, T. A., El-Gamil, M. M., and Abu El-Reash, G. M. (2018). Structural, thermogravimetric, B3LYP and biological studies on some heterocyclic thiosemicarbazide copper(II) complexes and evaluation of their molecular docking. J. Mol. Struct. 1151, 56-72. doi: 10.1016/j.molstruc.2017.09.035

Güniz Küçükgüzel, S., and Coşkun, G. P. (2016). Macromolecular drug targets in cancer treatment and thiosemicarbazides as anticancer agents. Anti Cancer Agents Med. Chem. 16, 1288-1300. doi: 10.2174/18715206166661602191 60256

Gutsche, C. D. (2008). Calixarenes: An Introduction. Cambridge: The Royal Society of Chemistry.

Gutsche, C. D., Dhawan, B., No, K. H., and Muthukrishnan, R. (1981). Calixarenes. 4 . The synthesis, characterization, and properties of the calixarenes from $p$-tertbutylphenol. J. Am. Chem. Soc. 103, 3782-3792. doi: 10.1021/ja00403a028
Hernández, W., Vaisberg, A. J., Tobar, M., Álvarez, M., Manzur, J., Echevarría, Y., et al. (2016). In vitro antiproliferative activity of palladium(II) thiosemicarbazone complexes and the corresponding functionalized chitosan coated magnetite nanoparticles. N. J. Chem. 40, 1853-1860. doi: 10.1039/C5NJ02429C

Homden, D. M., and Redshaw, C. (2008). The use of calixarenes in metal-based catalysis. Chem. Rev. 108, 5086-5130. doi: 10.1021/cr8002196

Karimi, N., Ghanbarzadeh, B., Hamishehkar, H., Mehramuz, B., and Kafil, H. S. (2018). Antioxidant, antimicrobial and physicochemical properties of turmeric extract-loaded nanostructured lipid carrier (NLC). Colloid Interface Sci. Commun. 22, 18-24. doi: 10.1016/j.colcom.2017.11.006

Liesen, A. P., de Aquino, T. M., Carvalho, C. S., Lima, V. T., de Araujo, J. M., de Lima, J. G., et al. (2010). Synthesis and evaluation of antiToxoplasma gondii and antimicrobial activities of thiosemicarbazides, 4thiazolidinones and 1,3,4-thiadiazoles. Eur. J. Med. Chem. 45, 3685-3691. doi: 10.1016/j.ejmech.2010.05.017

Mayer, F., Tiruvadi Krishnan, S., Schuhle, D. T., Eliseeva, S. V., Petoud, S., Toth, E., et al. (2018). Luminescence properties of self-aggregating Tb(III)-DOTAfunctionalized calix[4]arenes. Front. Chem. 6:1. doi: 10.3389/fchem.2018. 00001

Molnar, M., Tomić, M., and Pavić, V. (2018). Coumarinyl thiosemicarbazides as antimicrobial agents. Pharm. Chem. J. 51, 1078-1081. doi: $10.1007 / \mathrm{s} 11094-018-1743-3$

Mostafa, M. M. (2007). Spectroscopic studies of some thiosemicarbazide compounds derived from Girard's T and P. Spectrochim. Acta 66, 480-486. doi: 10.1016/j.saa.2006.02.063

Neri, P., Sessler, J. L., and Wang, M. X. (2016). Calixarenes and Beyond. Springer International Publishing, 1-1062.

Nimse, S. B., and Kim, T. (2013). Biological applications of functionalized calixarenes. Chem. Soc. Rev. 42, 366-386. doi: 10.1039/C2CS35233H

Perret, F., and Coleman, A. W. (2011). Biochemistry of anionic calix $[n]$ arenes. Chem. Commun. 47, 7303-7319. doi: 10.1039/c1cc11541c

Plech, T., Wujec, M., Siwek, A., Kosikowska, U., and Malm, A. (2011). Synthesis and antimicrobial activity of thiosemicarbazides, $s$-triazoles and their Mannich bases bearing 3-chlorophenyl moiety. Eur. J. Med. Chem. 46, 241-248. doi: 10.1016/j.ejmech.2010.11.010

Quiroga-Campano, C., Gómez-Machuca, H., Moris, S., Jara, P., De la Fuente, J. R., Pessoa-Mahana, H., et al. (2017). Synthesis of bifunctional receptor for fluoride and cadmium based on calix[4] arene with thiourea moieties. J. Mol. Struct. 1141, 133-141. doi: 10.1016/j.molstruc.2017.03.089

Rahimi, M., Karimian, R., Mostafidi, E., Bahojb Noruzi, E., Taghizadeh, S., Shokouhi, B., et al. (2018a). Highly branched amine-functionalized: psulfonatocalix[4]arene decorated with human plasma proteins as a smart, targeted, and stealthy nano-vehicle for the combination chemotherapy of MCF7 cells. N. J. Chem. 42, 13010-13024. doi: 10.1039/C8NJ01790E

Rahimi, M., Karimian, R., Noruzi, E. B., Ganbarov, K., Zarei, M., Kamounah, F. S., et al. (2019). Needle-shaped amphoteric calix[4]arene as a magnetic nanocarrier for simultaneous delivery of anticancer drugs to the breast cancer cells. Int. J. Nanomed. 14, 2619-2636. doi: 10.2147/IJN.S194596

Rahimi, M., Safa, K. D., and Salehi, R. (2017a). Co-delivery of doxorubicin and methotrexate by dendritic chitosan- $g$-mPEG as a magnetic nanocarrier for multi-drug delivery in combination chemotherapy. Polym. Chem. 8, 7333-7350. doi: 10.1039/C7PY01701D

Rahimi, M., Shafiei-Irannejad, V., Safa, K. D., and Salehi, R. (2018b). Multibranched ionic liquid-chitosan as a smart and biocompatible nano-vehicle for combination chemotherapy with stealth and targeted properties. Carbohydr. Polym. 196, 299-312. doi: 10.1016/j.carbpol.2018.05.059

Rahimi, M., Shojaei, S., Safa, K. D., Ghasemi, Z., Salehi, R., Yousefi, B., et al. (2017b). Biocompatible magnetic tris (2-aminoethyl) amine functionalized nanocrystalline cellulose as a novel nanocarrier for anticancer drug delivery of methotrexate. N. J. Chem. 41, 2160-2168. doi: 10.1039/C6NJ03332F

Rane, R. A., Naphade, S. S., Bangalore, P. K., Palkar, M. B., Shaikh, M. S., and Karpoormath, R. (2014). Synthesis of novel 4-nitropyrrole-based semicarbazide and thiosemicarbazide hybrids with antimicrobial and anti-tubercular activity. Bioorg. Med. Chem. Lett. 24, 3079-3083. doi: 10.1016/j.bmcl.2014.05.018

Rao, C. N. R., and Venkataraghavan, R. (1962). The C-S stretching frequency and the "-N-C-S bands" in the infrared. Spectrochim. Acta 18, 541-547. doi: 10.1016/S0371-1951(62)80164-7 
Rastogi, V. K., Palafox, M. A., Tanwar, R. P., and Mittal, L. (2002). 3, 5-Difluorobenzonitrile: $a b$ initio calculations, FTIR and Raman spectra. Spectrochim. Acta A Mol. Biomol. Spectrosc. 58, 1987-2004. doi: 10.1016/S1386-1425(01)00650-3

Salah, B. A., Kandil, A. T., and Abd El-Nasser, M. G. (2018). A therapeutic journey of semicarbazide and thio semicarbazide derivatives and their transition metals complexes: mini review. Res. Rev. J. Chem. 7:11.

Sarkar, T., Ashraf, P. M., Srinives, S., and Mulchandani, A. (2018). Calixarenefunctionalized single-walled carbon nanotubes for sensitive detection of volatile amines. Sens. Actuators B Chem. 268, 115-122. doi: 10.1016/j.snb.2018.04.078

Sgarlata, C., Brancatelli, G., Fortuna, C. G., Sciotto, D., Geremia, S., Bonaccorso, C. (2017). Three-dimensional network structures based on pyridyl-calix[4]arene metal complexes. Chempluschem 82, 1341-1350. doi: 10.1002/cplu.201700400

Shafiei-Irannejad, V., Samadi, N., Salehi, R., Yousefi, B., Rahimi, M., Akbarzadeh, A., et al. (2018). Reversion of multidrug resistance by co-encapsulation of doxorubicin and metformin in poly(lactide-co-glycolide)- $d$ - $\alpha$-tocopheryl polyethylene glycol 1000 succinate nanoparticles. Pharm. Res. 35:119. doi: 10.1007/s11095-018-2404-7

Shebl, M., Ibrahim, M. A., Khalil, S. M., Stefan, S. L., and Habib, H. (2013). Binary and ternary copper(II) complexes of a tridentate ONS ligand derived from 2aminochromone-3 carboxaldehyde and thiosemicarbazide: synthesis, spectral studies and antimicrobial activity. Spectrochim. Acta A Mol. Biomol. Spectrosc. 115, 399-408. doi: 10.1016/j.saa.2013.06.075

Shirakawa, S., and Shimizu, S. (2018). "Inherently chiral calix[4]arenes as supramolecular catalysts," in Designed Molecular Space in Material Science and Catalysis, ed S. Shirakawa (Singapore: Springer), 51-68.

Silverstein, R. M., Bassler, G. C., and Morrill, T. C. (1991). Spectrometric Identification of Organic Compounds, 5th Edn. New York, NY: Wiley.

Sliwa, W., and Girek, T. (2010). Calixarene complexes with metal ions. J. Incl. Phenom. Macrocyclic Chem. 66, 15-41. doi: 10.1007/s10847-009-9678-7

Sun, Y., Mei, Y., Quan, J., Xiao, X., Zhang, L., Tian, D., et al. (2016). The macroscopic wettable surface: fabricated by calix[4]arene-based hostguest interaction and chiral discrimination of glucose. Chem. Commun. 52, 14416-14418. doi: 10.1039/C6CC07956C

Teixeira, F. A., Marcos, P. M., Ascenso, J. R., Brancatelli, G., Hickey, N., and Geremia, S. (2017). Selective binding of spherical and linear anions by tetraphenyl(thio)urea-based dihomooxacalix[4]arene receptors. J. Org. Chem. 82, 11383-11390. doi: 10.1021/acs.joc.7b01801

Tong, Y. X., Su, C. Y., Zhang, Z. F., Kang, B. S., Yu, X. L., and Chen, X. M. (2000). Bis(thiosemicarbazide-S,N)zinc(II) dinitrate. Acta Crystallogr. Sect. C Cryst. Struct. Commun. 56, 44-45. doi: 10.1107/S0108270199012974

Weinstein, M. P., Limbago, B., Patel, J. B., Mathers, A. J., Campeau, S., Mazzulli, T., et al. (2018). M 100 Performance Standards for Antimicrobial Susceptibility Testing. Wayne, PA: Clinical and Laboratory Standards Institute.
William Anthony Coleman, L. G. B. (2010). Adina Nicoleta Lazar, Mickael Henri Michaud, Sandrine Magnard. Calixarene Derivatives as Anticancer Agent. US Patent 20100056482 A 1.

Xie, F., Cai, H., and Peng, F. (2018). Anti-prostate cancer activity of 8hydroxyquinoline-2-carboxaldehyde-thiosemicarbazide copper complexes in vivo by bioluminescence imaging. J. Biol. Inorg. Chem. 23, 949-956. doi: 10.1007/s00775-018-1596-y

Xie, F., and Peng, F. (2018). Anticancer activity of copper complex of (4R)(-)-2-thioxo-4-thiazolidinecarboxylic acid and 3-rhodaninepropionic acid on prostate and breast cancer cells by fluorescent microscopic imaging. J. Fluoresc. 28, 89-96. doi: 10.1007/s10895-017-2177-0

Yamamoto, T., Sugiyama, S., Akimoto, K., and Hayashi, K. (1992). One-pot synthesis of isothiocyanates from primary amines synthesis using cyanamide? Org. Preparations Proced. Int. 24, 346-349. doi: 10.1080/003049492093 55899

Yang, R., Shen, X. Q., Mao, H. Y., Zhang, H. Y., Wu, Q. A., Wang, H., et al. (2006). Synthesis and crystal structure of a novel supra-molecular compound [Co(tsc)2][NPA $] 2 \cdot 4 \mathrm{H}_{2} \mathrm{O}$ (tsc = thiosemicarbazide, $\mathrm{H}_{2} \mathrm{NPA}=3$-nitro-phthalic acid). Synth. Reactivity Inorg. Metal Org. Nano Met. Chem. 36, 617-620. doi: 10.1080/15533170600910538

Yeon, Y., Leem, S., Wagen, C., Lynch, V. M., Kim, S. K., and Sessler, J. L. (2016). 3-(Dicyanomethylidene)indan-1-one-functionalized calix[4]arenecalix[4]pyrrole hybrid: an ion-pair sensor for cesium salts. Org. Lett. 18, 4396-4399. doi: 10.1021/acs.orglett.6b02155

Yousef, T. A., Abu El-Reash, G. M., El-Gamal, O., and Sharaa, B. M. (2018). Ligational, DFT, optical band gap and biological studies on $\mathrm{Mn}$ (II), Co(II) and $\mathrm{Ni}(\mathrm{II})$ complexes of ethyl and allyl thiosemicarbazides ending by thiazole group. J. Mol. Liquids 251, 423-437. doi: 10.1016/j.molliq.2017. 12.022

Zhang, W.-C., and Huang, Z.-T. (1997). Synthesis of 4-tert-butylcalix[4]arenes bearing two Schiff-base units at the lower rim. Synthesis 1997, 1073-1076. doi: $10.1055 /$ s-1997-1308

Conflict of Interest: The authors declare that the research was conducted in the absence of any commercial or financial relationships that could be construed as a potential conflict of interest.

Copyright (c) 2019 Bahojb Noruzi, Kheirkhahi, Shaabani, Geremia, Hickey, Asaro, Nitti and Kafil. This is an open-access article distributed under the terms of the Creative Commons Attribution License (CC BY). The use, distribution or reproduction in other forums is permitted, provided the original author $(s)$ and the copyright owner(s) are credited and that the original publication in this journal is cited, in accordance with accepted academic practice. No use, distribution or reproduction is permitted which does not comply with these terms. 